\title{
COUPLING STUDY OF ECONOMIC VALUE, ECOLOGICAL VALUE AND SOCIAL VALUE OF FORESTS
}

\author{
ZHAO, X. - YUE, S.* \\ Northeast Forestry University College of Economics and Management \\ 26 Hexing Rd, Xiangfang Qu, Haerbin Shi, Heilongjiang Sheng, China \\ (e-mail:229335982@qq.com) \\ ${ }^{*}$ Corresponding author \\ e-mail: yueshngzhi@126.com \\ (Received $8^{\text {th }}$ Mar 2019; accepted 21 $1^{\text {st }}$ May 2019)
}

\begin{abstract}
This paper uses potential function to build a coupling model: firstly, it divides forest value into three subsystems including economic value, ecological value, and social value, and set the index according to their characteristics; then it studies empirically the coupling relationship among economic value, ecological value, and social value of forest in China from 2008 to 2016. The results show that from 2008 to 2016, the overall coordination among economic value, ecological value, and social value of forest in China is poor while the overall trend is continuous growing, and ecological value of forest has a higher weight. In the future, China should pay attention to the development, protection and utilization of ecological forest value to achieve their sustainable development.
\end{abstract}

Keywords: sustainable development, overall coordination, coupling model, subsystem, environmental science

\section{Introduction}

Forests are the larges ecosystems on land, supporting the humanity's important mission of sustainable development, regulation of ecological balance, and development of low-carbon economy ( $\mathrm{Li}$ and Zhao, 2017). With the changes in current social environment and natural economic environment, human beings traditional use pattern of forest could no longer meet the needs of modern economic development.

On the one hand, the sustainable growth of the forestry industry economy is inseparable from the demand for forest resources; on the other hand, the deteriorating ecological environment and people's demand for a better society require us to protect the only remaining forest resources. In terms of the products and functions provided by forest, it can not only provide ecological services such as water conservation, carbon fixation and oxygen production, and air purification, etc. but also develop tourism; it is also a major production materials for the manufacturing industry, promoting economic development (Chen et al., 2017). For this reason, ways to develop forest resources and maximize their own value is of particular importance. Should we protect forest ecological environment or develop forestry economic industry? And what is the 
relationship between these two? This issue has become one of the key forest issues for scholars' research. From the perspective of value, Deng et al. (2002) use "shadow engineering" and other methods to study the value of water conservation in the forest ecosystem in the upper reaches of the Yangtze River, Zhang and Khalique (2018) showing that the annual economic value of water conservation in the forest ecosystem is 160.6179 billion yuan (equivalent to a quarter of the GDP in that region in 1999), and the forest ecosystem is so effective for human beings that the country should pay attention to and protect the ecological value of forest. Through the evaluation method combining quality and value, Zhang et al. (2007) and Shrestha and Baral (2018) use shadow engineering approach, market value approach, and production cost, etc. to quantitatively study the service value of forest ecosystem in Gansu Province. The results show that the economic value of water conservation in the forest ecosystem in Gansu is 256 million yuan/a; the economic value of forest-maintained soil is 4.748 billion yuan/a; the value of forest purified water is 248 million yuan/a; the value of $\mathrm{CO}_{2}$ fixation is 11.532 billion yuan/a; the value of $\mathrm{O}_{2}$ release is 13.124 billion yuan/a; the value of $\mathrm{SO}_{2}$ absorption is 388 million yuan/a; the value of dust retention is 15.639 billion yuan/a; and the value of forest ecological service function in Gansu Province is 44.712 billion yuan, accounting for $23.19 \%$ of the province's GNP. These help to see visually the important role of the ecological value of forest, requiring formulation of more reasonable operation model to achieve sustainable development of ecological economy. Pang et al. (2016), Cong et al. (2017) and Austin et al. (2018) use distributed measurement to evaluate the service value of forest ecosystem in Helan Mountain National Nature Reserve in Ningxia. The results show that the total value of forest ecological service function in that region in 2015 was 1.68708 billion yuan/a, accounting for $6.68 \%$ of the gross output value of agriculture, forestry, animal husbandry, sideline production, and fishery in Ningxia Autonomous Region in 2014; while the total forest area of the nature reserve accounts for $3.03 \%$ of the land area of Ningxia Autonomous Region, indicating that forest ecosystem can not only provide forestry by-product value but also has huge ecological value. Wang et al. (2015) take the analysis of increasing demand for tourism in national forest parks as well as the ecological environment and tourist needs of the scenic spot as background, use choice experiment method and conditional Logit model to empirically analyze the main attributes of Shenyang National Forest Park and evaluate its economic value (Zhang et al., 2017). The results show that vegetation coverage, water clarity, garbage quantity, and crowding degree all have significant impact on the recreation effect. The current economic value of the scenic spot is 27.3 yuan per person, however, when vegetation coverage increases by $10 \%$ every time, the economic value of the park will increase 30 yuan; when water clarity improves $0.5 \mathrm{~m}$ every time, the economic value of the park will increase 24 yuan; when garbage quantity increase 5 pieces every $20 \mathrm{~m}^{2}$, the economic value of the park will decrease 20 yuan (Olivares et al., 2017). It can be seen that changing the ecological environment plays an important role in improving the 
economic and social benefits of national forest parks. Wang et al. (2015) and Ali et al. (2018) start from the perspective of producers to calculate the recreational value of 39 forest parks in Qinling via marginal opportunity cost method. The results show that the total value of forest recreation is 21.63 billion yuan while the ecological value of forest itself accounts for $74.12 \%$, showing that the ecological function of forest itself can better promote the development of forest tourism. From the perspective of theoretical innovation, Liu and Huang (2007) and Jamil et al. (2018) make theoretical innovation from interest-orientation principle, public product theory, and spillover benefit correction theory to coordinate the relationship between forestry ecological benefits and economic benefits; they also propose to rely on market mechanism to adjust the average level of profit by government imputing certain profit parameters to the market so that both forestry activities with or without lumbering can achieve social average profit. Based on complex system theory, Dong and Zhang (2013) use gray correlation evaluation model, and take the calculation method of slope correlation to build a coupling model of the forestry industry and the forest ecosystem; they also take Yichun Shuangfeng Forestry Bureau as an example (Marina et al., 2013; Gautam et al., 2019), and conduct experimental study to find that the degree of coupling between forestry industry and forest ecosystem in that area is 0.47 , thus further draw the conclusion that the relationship between forestry industry development and forest ecosystem in that area is moderate and their relevant impact is general (Liao and Zhang, 2017; Tao, 2018). It can be seen that the researches on forest value by Chinese and foreign experts and scholars stays on the basis of comparison to obtain the ratio of the ecological value of the forest to the total value or the differences between the social value of forest and the income that is already earned, while they do not involve the degree of relationship among the three or the content of coordination relationship. This study conducts an empirical study by building a coupling relationship model of the economic value, ecological value, and social value of forest (Dong et al., 2017), trying to explain the coordination relationship among the three major values of forest and provide a theoretical basis for specifying the future development of forest value.

\section{Materials and Methods}

Coupling, in physics, refers to the phenomenon in which two or more systems or two forms of motion connect by impact on each other through various interactions, and such dynamic phenomenon is also called coupling effect. The coordination degree of coupling effect is related to dynamic cycle operation of the whole system; at the same time (Zhang, 2016; Dali and Kamarudin, 2018), it can also reflect the coordination state of the development of things that strong coordination means good development while discordance or conflict means development degeneration or stagnation. Coupling effect has been widely used in many fields including sociology, ecology, and economics, etc. based on its characteristics (Wu et al., 2014; Sarwar et al., 2019). This study applies this 
concept to analyze the coordination relationship and dynamic development relationship among social value, economic value, and ecological value of forest, providing a theoretical basis for future forest value enhancement and forest sustainable development. The premise of presenting the efficacy of economic value, ecological value, and social value of forest is to build a potential function based on coupling effect. Assume U1 represents the economic value subsystem of forest, U2 represents the ecological value subsystem of forest, U3 represents the social value subsystem of forest (Zhou et al., 2018; Babaranti et al., 2019), and $u_{i j}$ represents the observation value of the jth statistical indicator in subsystem $i$, then the potential function of subsystem $i$, subsystem $j$, and subsystem $\mathrm{z}$ is $(E q .1)$ :

$$
U_{i}=\sum_{j=1}^{n} \omega_{i j} \mu_{i j}, U_{j}=\sum_{i=1}^{m} \omega_{i j} \mu_{i j}, U_{z}=\sum_{j=1}^{n} \omega_{z j} \mu_{z j}
$$

where $\mu_{i j}$ represents the normalized value of the jth statistical indicator in subsystem i. The normalized processing formulae for this value include positive normalization and negative normalization, respectively (Eq.2):

$$
\begin{aligned}
& \mu_{1}=\left[\mu_{i j}-\min \mu_{i j} / \max \mu_{i j}-\min \mu_{i j}\right] \times 0.9+0.1 \\
& \mu_{2}=\left[\min \mu_{i j}-\mu_{i j} / \max \mu_{i j}-\min \mu_{i j}\right] \times 0.9+0.1
\end{aligned}
$$

$\omega_{i j}$ represents the weight of the jth statistical indicator in subsystem $\mathrm{i}$, and meets the following condition (Eq.3):

$$
\sum_{j=1}^{n} \omega_{i j}=1, \sum_{i=1}^{m} \omega_{i j}=1
$$

Based on the coupling model built by potential function, the generalized expression of the n-dimensional coupling degree model is (Eq.4):

$$
H_{n}=n\left(U_{1} U_{2} U_{3} \cdots U_{n} / \Pi\left(U_{i}+U_{j}+U_{z}\right)\right)^{\frac{1}{n}}
$$

Since the subsystems involved in this study are economic value, social value, and ecological value of forest, the coupling models of the following three subsystems can be derived (Eq.5):

$$
H_{3}=3\left(U_{1} U_{2} U_{3} / \Pi\left(U_{1}+U_{2}+U_{3}\right)\right)^{\frac{1}{3}}
$$

where $\mathrm{H}$ represents the direct coupling degree of each subsystem (Pascual-Córdova, 2018). The value range is $[0,1]$. Higher $H$ value means higher coupling degree of each 
subsystem, better coordination among systems, and benign and healthy development of the whole system; and lower $\mathrm{H}$ value means lower coupling degree of each subsystem, worse coordination among systems, and stagnant or degraded development of the whole system.

In order to further measure the overall coordination degree and efficacy coordination of the system (Yang et al., 2019; Majumder et al., 2019), we also need to formulate a coupling coordination function to measure the coupling degree among economic value, social value, and ecological value of forest in China. The expression formula of $\mathrm{D}$ the coupling coordination function is (Eq.Ø):

$$
D:\left\{\begin{array}{c}
T=(H \times C) \times k \\
C=\alpha U_{1}+\beta U_{2}+\gamma U_{3}
\end{array}\right.
$$

where T represents the coupling coordination degree among economic value subsystem, social value subsystem, and ecological value subsystem of forest; $\mathrm{H}$ represents the degree of coupling among the subsystems; $\mathrm{C}$ represents the coordination coefficient among the subsystems; $\mathrm{k}, \alpha, \beta$, and $\gamma$ are parameters; $\mathrm{k}$ is a constant quantity value of $0.5 ; \alpha, \beta$, and $\gamma$ are determined in accordance with the degrees of importance of the economic value, social value, and ecological value of forest in total value of forest. This study first assumes the values of $\alpha, \beta$ and $\gamma$ are 0.33 - in equally important position.

In accordance with the coupling relationship among economic value, social value, and ecological value of forest, such coupling relationship can be divided into three categories: sound development, moderate development and slow development; and the coordination degree can be divided into five levels: excellent coordination, good coordination, moderate coordination, weak coordination, and poor coordination. The details are shown in Table 1.

\section{Results}

Based on the existing research and the principles of scientificity, reliability, systematicness, availability, and measurability, etc., this study selects appropriate measurement index, uses the combination of qualitative and quantitative methods to express the data, and conducts a comparative study of index data to achieve accurate measurement results with more reference valuable. The evaluation system designed in this study includes three subsystems, namely economic value of forest, ecological value of forest and social value of forest. Economic value of forest is mainly reflected in the two aspects including economic benefit and economic structure. 
Table 1. Classification relationship of forest value coordination degree

\begin{tabular}{|c|c|c|c|c|}
\hline Category & Grade & Coordination degree $(\mathbf{T})$ & Relationship & Meaning \\
\hline \multirow{12}{*}{$\begin{array}{c}\text { Sound } \\
\text { development }\end{array}$} & \multirow{6}{*}{$\begin{array}{c}\text { Excellent } \\
\text { coordination }\end{array}$} & \multirow{6}{*}{$0.8<\mathrm{T} \leq 1$} & $\mathrm{U} 1>\mathrm{U} 2>\mathrm{U} 3$ & Highly coordinated development, economic value $>$ ecological value $>$ social value \\
\hline & & & $\mathrm{U} 2>\mathrm{U} 1>\mathrm{U} 3$ & Highly coordinated development, ecological value $>$ economic value $>$ social value \\
\hline & & & $\mathrm{U} 3>\mathrm{U} 1>\mathrm{U} 2$ & Highly coordinated development, social value $>$ economic value $>$ ecological value \\
\hline & & & $\mathrm{U} 3>\mathrm{U} 2>\mathrm{U} 1$ & Highly coordinated development, social value $>$ ecological value $>$ economic value \\
\hline & & & $\mathrm{U} 1>\mathrm{U} 3>\mathrm{U} 2$ & Highly coordinated development, economic value $>$ social value $>$ ecological value \\
\hline & & & $\mathrm{U} 2>\mathrm{U} 3>\mathrm{U} 1$ & Highly coordinated development, ecological value $>$ social value $>$ economic value \\
\hline & \multirow{6}{*}{ Good coordination } & \multirow{6}{*}{$0.6<\mathrm{T} \leq 0.8$} & $\mathrm{U} 1>\mathrm{U} 2>\mathrm{U} 3$ & Sound coordinated development, economic value $>$ ecological value $>$ social value \\
\hline & & & $\mathrm{U} 2>\mathrm{U} 1>\mathrm{U} 3$ & Sound coordinated development, ecological value $>$ economic value $>$ social value \\
\hline & & & $\mathrm{U} 3>\mathrm{U} 1>\mathrm{U} 2$ & Sound coordinated development, social value $>$ economic value $>$ ecological value \\
\hline & & & $\mathrm{U} 3>\mathrm{U} 2>\mathrm{U} 1$ & Sound coordinated development, social value $>$ ecological value $>$ economic value \\
\hline & & & $\mathrm{U} 1>\mathrm{U} 3>\mathrm{U} 2$ & Sound coordinated development, economic value $>$ social value $>$ ecological value \\
\hline & & & $\mathrm{U} 2>\mathrm{U} 3>\mathrm{U} 1$ & Sound coordinated development, ecological value $>$ social value $>$ economic value \\
\hline \multirow{6}{*}{$\begin{array}{c}\text { Moderate } \\
\text { development }\end{array}$} & \multirow{6}{*}{$\begin{array}{l}\text { Moderate } \\
\text { coordination }\end{array}$} & \multirow{6}{*}{$0.4<\mathrm{T} \leq 0.6$} & $\mathrm{U} 1>\mathrm{U} 2>\mathrm{U} 3$ & Moderate coordinated development, economic value $>$ ecological value $>$ social value \\
\hline & & & $\mathrm{U} 2>\mathrm{U} 1>\mathrm{U} 3$ & Moderate coordinated development, ecological value $>$ economic value $>$ social value \\
\hline & & & $\mathrm{U} 3>\mathrm{U} 1>\mathrm{U} 2$ & Moderate coordinated development, social value $>$ economic value $>$ ecological value \\
\hline & & & $\mathrm{U} 3>\mathrm{U} 2>\mathrm{U} 1$ & Moderate coordinated development, social value $>$ ecological value $>$ economic value \\
\hline & & & $\mathrm{U} 1>\mathrm{U} 3>\mathrm{U} 2$ & Moderate coordinated development, economic value $>$ social value $>$ ecological value \\
\hline & & & $\mathrm{U} 2>\mathrm{U} 3>\mathrm{U} 1$ & Moderate coordinated development, ecological value $>$ social value $>$ economic value \\
\hline
\end{tabular}




\begin{tabular}{|c|c|c|c|c|}
\hline Category & Grade & Coordination degree $(\mathrm{T})$ & Relationship & Meaning \\
\hline \multirow{12}{*}{$\begin{array}{c}\text { Slow } \\
\text { development }\end{array}$} & \multirow{6}{*}{ Weak coordination } & \multirow{6}{*}{$0.2<\mathrm{T} \leq 0.4$} & $\mathrm{U} 1>\mathrm{U} 2>\mathrm{U} 3$ & Weak coordinated development, economic value $>$ ecological value $>$ social value \\
\hline & & & $\mathrm{U} 2>\mathrm{U} 1>\mathrm{U} 3$ & Weak coordinated development, ecological value $>$ economic value $>$ social value \\
\hline & & & $\mathrm{U} 3>\mathrm{U} 1>\mathrm{U} 2$ & Weak coordinated development, social value $>$ economic value $>$ ecological value \\
\hline & & & $\mathrm{U} 3>\mathrm{U} 2>\mathrm{U} 1$ & Weak coordinated development, social value $>$ ecological value $>$ economic value \\
\hline & & & $\mathrm{U} 1>\mathrm{U} 3>\mathrm{U} 2$ & Weak coordinated development, economic value $>$ social value $>$ ecological value \\
\hline & & & $\mathrm{U} 2>\mathrm{U} 3>\mathrm{U} 1$ & Weak coordinated development, ecological value $>$ social value $>$ economic value \\
\hline & \multirow{6}{*}{ Poor coordination } & \multirow{6}{*}{$0<\mathrm{T} \leq 0.2$} & $\mathrm{U} 1>\mathrm{U} 2>\mathrm{U} 3$ & Poor coordinated development, economic value $>$ ecological value $>$ social value \\
\hline & & & $\mathrm{U} 2>\mathrm{U} 1>\mathrm{U} 3$ & Poor coordinated development, ecological value $>$ economic value $>$ social value \\
\hline & & & $\mathrm{U} 3>\mathrm{U} 1>\mathrm{U} 2$ & Poor coordinated development, social value $>$ economic value $>$ ecological value \\
\hline & & & $\mathrm{U} 3>\mathrm{U} 2>\mathrm{U} 1$ & Poor coordinated development, social value $>$ ecological value $>$ economic value \\
\hline & & & $\mathrm{U} 1>\mathrm{U} 3>\mathrm{U} 2$ & Poor coordinated development, economic value $>$ social value $>$ ecological value \\
\hline & & & $\mathrm{U} 2>\mathrm{U} 3>\mathrm{U} 1$ & Poor coordinated development, ecological value $>$ social value $>$ economic value \\
\hline
\end{tabular}


Economic benefit is objective expression of the total amount of forest economy, mainly in five aspects: (1) total output value of forestry industry, namely the sum of the value created by various production and processing based on forestry industry; (2) contribution rate of forestry industry, namely the ratio of the total output value increase of forestry in national GDP growth; (3) the central government's investment amount in the development of forestry economy, namely state's funds for ecological construction, ecological compensation, and forest disaster management; (4) investment amount of local finance in forestry economic development, namely local governments' construction capital for forestry economic development, and (5) ecological construction and protection funds, namely the central and local governments' total ecological compensation that is absorbed because of the ecological benefits of forestry industry.

Forestry economic structure shows the resource allocation of forestry resource elements in various industries, and the industrial structure of forestry is an important factor to promote the development of forestry economy. This study chooses the structural proportions of various industries in forestry industry to reflect if the forestry industry structure is reasonable. By referring to the evaluation system of forest ecological status in Specifications for Assessment of Forest Ecosystem Services in China and National Level Criteria and Indicators of Sustainable Forest Management in China, this study's selection of forest ecological index mainly reflects the ecological basis, ecological structure, forest health, and ecological protection of forest. Ecological basis of forest mainly focuses on three aspects: (1) forest coverage rate, namely the proportion of forest area on land, the degree of greening of land, and the abundance of ecological resources in China; (2) the amount of forest reserves, namely the total amount of various kinds of forest wood in the forests; and (3) afforestation area, the sum of national afforestation area each year. Ecological structure reflects the accumulation of each forest species. Forest health mainly investigates disaster situation of forests. The indicator system of ecological protection function is established based on the indicator system of ecological service of forest. As there are multiple methods to estimate the value of ecological service of forest, and the measurement of some physical quantities cannot be objective and accurate, this study chooses the construction situation of ecological protection projects of forest to reflect the service function of forest. The first is the natural forest protection project. Natural forest has natural advantages that artificial forest cannot match, including great biodiversity, strong self-recovering ability and adaptability to environment and anti-disaster ability. It can better exert forests' functions of water conservation, climate regulation, and biodiversity increase, therefore the construction area of natural forest protection project can reflect the ecological benefits of forests. The second is the project of returning farmland to forests. This project is one of the important national policies for implementing the western development strategy in China. It can improve soil erosion and desert wasteland; at the same time, number of its acres can also be used as a basis for national subsidy. The third is the sand control project. It can improve wind prevention and sand fixation of forest to further reflect the ecological 
service value of wind prevention and sand fixation of forest. The fourth is the shelter forest system project. It can resist natural disasters, protect infrastructure and production, improve the environment, maintain ecological peace, and reduce pollution, etc. In accordance with different protection purposes, we can establish various forests with ecological service functions such as water conservation forest, soil and water conservation forest, and landscape shelter forests, etc. Therefore the construction area of shelter forest can be regarded as an important indicator that reflects the ecological protection function. The fifth is the area of nature reserve. This can be taken as an indicator that has impact on the biodiversity of forest. The sixth is the value of forestry ecological service. This is the value of forestry ecological service that has formed industrial activities in the tertiary industry of forestry, e.g. recreation in forest, soil and water conservation, carbon sequestration, and conservation of biodiversity, etc. For social value of forest, as its accounting system is not complete and there are no national accounting indicators, this study integrates the existing literature research and divides the social value of forest in three aspects - value of people's livelihood, value of tourism, and value of culture. Value of people's livelihood uses the number of forestry employees and their average salary to reflect the beneficial contribution of forestry economic development to society. Value of tourism uses the tourism and leisure service value of forestry for reflection. And value of culture reflects the abstract value of forest. Therefore, this study chooses the approximate forest park area and popularity index of forest park to alternatively reflect the cultural value of the forest (Meza, 2018).

Since there is a certain difference in the importance of indicators in different systems, the indicators need to be weighted before coupling analysis. At present, the weighted analysis methods (e.g. expert investigation and analytic hierarchy process) used by most scholars have strong subjectivity; therefore the obtained index weights may have some errors. This study uses objective weighting method and entropy method based on the variation coefficient of objective things to weight each indicator. Specific steps are as follows:

(1) Standardize the index by standardized formula (Eq.7):

$$
y_{i}=x_{i}-\bar{x} / s
$$

where $y$ represents the value after standardization and $\mathrm{s}$ is standard deviation with the formula as (Eq.8):

$$
s=\sqrt{\frac{1}{n-1} \sum_{i=1}^{n}\left(x_{i}-\bar{x}\right)^{2}}
$$

$\bar{x}$ is the average of the variables with the calculation formula as (Eq.9):

$$
\bar{x}=\frac{1}{n} \sum_{i=1}^{n} x_{i}
$$


After standardization, different data variables have the same variance and mean value, so they can be directly compared.

(2) Calculate the proportion of the standardized values in the subsystem, $a_{i j}$ represents the proportion of indicator $\mathrm{j}$ in subsystem $\mathrm{i}$ in the standardized subsystem, and $u_{i j}$ represents the standardized value of indicator $\mathrm{j}$ in subsystem $\mathrm{i}$, the formula is (Eq.10):

$$
a_{i j}=u_{i j} / \sum_{i=1}^{n} u_{i j}
$$

The entropy value $p_{j}$ of indicator $\mathrm{j}$ in subsystem $\mathrm{i}$ can be calculated in accordance with the formula $(E q .11)$ :

$$
p_{j}=-k \sum_{i=1}^{n} a_{i j} \ln a_{i j}, k=\frac{1}{\ln (n)}>0
$$

where $\mathrm{k}$ is coordinating parameter.

(3) Calculate the variation coefficient 1 of indicator $j$ in subsystem $i$, the formula is (Eq.12):

$$
l_{j}=1-p_{j} / m-g_{p},\left(g_{p}=\sum_{j=1}^{m} p_{j}\right)
$$

(4) The calculation formula for the weight $\omega_{j}$ of indicator $\mathrm{j}$ in subsystem $\mathrm{i}$ is (Eq.13):

$$
\omega_{j}=l_{j} / \sum_{j=1}^{m} l_{j}, j=1,2,3 \cdots, m
$$

The weights of the indicators in each system calculated with this method are shown in Table 2.

\section{Discussion}

As an important resource asset, forest can not only provide timber and other plant assets for the development of national economy and people's life, but also functions as an important environmental asset and the largest environmental carrier on land with a basic status in developing low-carbon economy and ecological civilization; meanwhile, as an important part of terrestrial ecosystem, forest is also the habitat of biodiversity, playing the role of water conservation, soil conservation, wind prevention and sand fixation, and climate regulation and change, etc. while functioning as the important site to absorb carbon dioxide and sulfur dioxide (Hernández, 2019). It undertakes two major missions of optimizing environment and promoting production. General Secretary Xi Jinping also proposes that we need both valuable assets, and more importantly, lucid waters and lush mountains; after all, lucid waters and lush mountains are invaluable assets. 
Table 2. Index setting and index weight

\begin{tabular}{|c|c|c|c|c|}
\hline Subsystem & Primary index & Secondary index & Unit & Weight \\
\hline \multirow{8}{*}{$\begin{array}{c}\text { Economic } \\
\text { value of forest } \\
\mathrm{U} 1\end{array}$} & \multirow{5}{*}{$\begin{array}{c}\text { Economic benefit } \\
\text { level U11 }\end{array}$} & Total output value of forestry industry U111 & 100 million yuan & 0.031 \\
\hline & & Contribution rate of forestry industry U112 & $\%$ & 0.016 \\
\hline & & The central government's investment amount U113 & 100 million yuan & 0.022 \\
\hline & & Investment amount of local finance U114 & 100 million yuan & 0.031 \\
\hline & & Ecological construction and protection funds U115 & 100 million yuan & 0.019 \\
\hline & \multirow{3}{*}{$\begin{array}{c}\text { Economic } \\
\text { structure U12 }\end{array}$} & $\begin{array}{l}\text { Proportion of the output value of the primary industry } \\
\qquad \text { U121 }\end{array}$ & $\%$ & 0.048 \\
\hline & & $\begin{array}{l}\text { Proportion of the output value of the secondary industry } \\
\qquad \text { U122 }\end{array}$ & $\%$ & 0.018 \\
\hline & & $\begin{array}{l}\text { Proportion of the output value of the tertiary industry } \\
\qquad \text { U123 }\end{array}$ & $\%$ & 0.044 \\
\hline \multirow{13}{*}{$\begin{array}{c}\text { Ecological } \\
\text { value of forest } \\
\mathrm{U} 2\end{array}$} & \multirow{3}{*}{$\begin{array}{c}\text { Ecological basis } \\
\mathrm{U} 21\end{array}$} & Forest coverage rate $\mathrm{U} 211$ & $\%$ & 0.079 \\
\hline & & The amount of forest reserves U212 & $10,000 \mathrm{~m}^{3}$ & 0.079 \\
\hline & & Afforestation area U213 & hectare & 0.092 \\
\hline & \multirow{2}{*}{$\begin{array}{c}\text { Ecological } \\
\text { structure U22 }\end{array}$} & Natural forest quantity U221 & $10,000 \mathrm{~m}^{3}$ & 0.030 \\
\hline & & Plantation quantity U222 & $10,000 \mathrm{~m}^{3}$ & 0.079 \\
\hline & \multirow{2}{*}{ Forest health U23 } & Area of forest fire $\mathrm{U} 231$ & hectare & 0.025 \\
\hline & & Area of pests and diseases in forest $\mathrm{U} 232$ & hectare & 0.035 \\
\hline & \multirow{6}{*}{$\begin{array}{l}\text { Ecological } \\
\text { protection } \\
\text { function U24 }\end{array}$} & Natural forest protection project U241 & hectare & 0.051 \\
\hline & & Project of returning farmland to forests U242 & hectare & 0.021 \\
\hline & & Sand control project $\mathrm{U} 243$ & hectare & 0.037 \\
\hline & & Shelter forest system project U244 & hectare & 0.033 \\
\hline & & The area of nature reserve U245 & hectare & 0.034 \\
\hline & & Value of forestry ecological service U246 & 100 million yuan & 0.032 \\
\hline \multirow{5}{*}{$\begin{array}{c}\text { Social } \\
\text { valueU3 }\end{array}$} & \multirow{2}{*}{$\begin{array}{c}\text { Value of people's } \\
\text { livelihood U31 }\end{array}$} & Employed populationU311 & person & 0.018 \\
\hline & & Average annual salary of in-service employees U312 & 100 million yuan & 0.033 \\
\hline & $\begin{array}{c}\text { Tourism value of } \\
\text { forest } \mathrm{U} 32\end{array}$ & Recreation value of forest U321 & 100 million yuan & 0.041 \\
\hline & \multirow{2}{*}{$\begin{array}{l}\text { Cultural value of } \\
\text { forest } \mathrm{U} 33\end{array}$} & Area of forest park U331 & hectare & 0.028 \\
\hline & & Popularity index of forest park U332 & $\%$ & 0.016 \\
\hline
\end{tabular}

Therefore, it is an inevitable choice for forestry sustainable development to implement win-win development of forestry with coordination of economic, social and ecological environment, and maximize the economic value, social value and ecological value of forest on the basis of adhering to the virtuous cycle of ecological environment. Under this 
development trend, this study chooses the original data in China Forestry Statistical Yearbook from 2008 to 2016 for coupling degree analysis, trying to indicate the direction for future sustainable development of forestry in China through the research results in addition to analyzing the relationship among the three major values of forests (Shan and Lai, 2018).

First, the original data is standardized; then the weight of each index system is calculated by "entropy weight method" and the calculation result is brought into the potential function to obtain the values of economic value, ecological value and social value of forest; finally, coupling model and coupling coordination model are used to calculate the final results shown in Tables 3 and 4.

Table 3. 2008 to 2016 calculation result of coupling value $H$

\begin{tabular}{c|c|c|c|c|c|c|c|c}
\hline $\mathbf{2 0 0 8}$ & $\mathbf{2 0 0 9}$ & $\mathbf{2 0 1 0}$ & $\mathbf{2 0 1 1}$ & $\mathbf{2 0 1 2}$ & $\mathbf{2 0 1 3}$ & $\mathbf{2 0 1 4}$ & $\mathbf{2 0 1 5}$ & $\mathbf{2 0 1 6}$ \\
\hline 0.724 & 0.729 & 0.877 & 0.926 & 0.948 & 0.781 & 0.861 & 0.796 & 0.841 \\
\hline
\end{tabular}

Table 4. 2008 to 2016 calculation result of coupling coordination value $T$

\begin{tabular}{c|c|c|c|c|c|c|c|c}
\hline $\mathbf{2 0 0 8}$ & $\mathbf{2 0 0 9}$ & $\mathbf{2 0 1 0}$ & $\mathbf{2 0 1 1}$ & $\mathbf{2 0 1 2}$ & $\mathbf{2 0 1 3}$ & $\mathbf{2 0 1 4}$ & $\mathbf{2 0 1 5}$ & $\mathbf{2 0 1 6}$ \\
\hline 0.048 & 0.064 & 0.077 & 0.084 & 0.105 & 0.153 & 0.155 & 0.189 & 0.203 \\
\hline
\end{tabular}

Table 3 is the coupling values of the economic value, ecological value and social value of forest. In accordance with the coupling degree indicator $\mathrm{H}$ described above, the value range is 0 to 1 , higher value means higher coupling degree, and conversely, lower value means lower coupling degree. It can be seen from the data in Table 3 that the coupling degree among economic value, ecological value and social value of forest is high with the average value of all values reaching 0.83 , proving the great influence among the economic value, ecological value and social value of forest; the coupling degree increased year by year from 2008 to 2012, showing that the country has made basic achievements in forestry construction since the reform and opening up, a series of initiatives such as the construction of six major ecological protection projects, development of forest tourism, rapid development of the forestry tertiary industry, and continuous implementation of national policy to change desertification have made the value of forest more and more prominent, and the values of forest are moving toward healthy and good development trend steadily.

It can be seen from Table 4 that the coupling coordination value $\mathrm{T}$ of the economic value, ecological value and social value of forest in China from 2008 to 2016 also shows an increasing trend year by year; however, if graded by coordination degree, the coordination differences from 2008 to 2015 were basically in the same level while the 
coordination degree in 2016 was weaker with one level up compared with the previous, but the value was not high. The biggest increase was in 2013, this is mainly because since the $18^{\text {th }}$ CPC National Congress, General Secretary Xi Jinping has put forward a series of important speeches on promoting the construction of ecological civilization and made a series of important instructions and profound discussions, while forest, as a main part and important resource of ecosystem on land, is an important ecological guarantee for the survival and development of human beings. Under such background, State Forestry Administration organized experts to prepare Outline of State Forestry Administration's Plan for Promoting Ecological Civilization Construction, which clearly defined the national ecological red line, requiring the forest stock volume of no less than 20 billion cubic meters, so the afforestation area in 2013 increased by 504,270 thousand hectares compared with 2012. However, the growth rate of the ecological value indicators of forest in 2014 decreased compared with that in 2013, resulting in the least increase in the coupling coordination value in 2014. From an overall perspective, the development of the economic value, ecological value and social value of forest in China is transiting from incoordination to coordination. From the perspective of the system's potential function, as shown in the following table (Table 5), the ecological value of forest is also significantly higher than the economic value and social value of forest (Wang, 2019).

Table 5. Potential functions of sub-systems of forest

\begin{tabular}{c|c|c|c}
\hline Year & Economic value of forest & Ecological value of forest & Social value of forest \\
\hline $\mathbf{2 0 0 8}$ & 0.05890141 & 0.1270031 & 0.01534795 \\
$\mathbf{2 0 0 9}$ & 0.05427371 & 0.1832762 & 0.02660406 \\
$\mathbf{2 0 1 0}$ & 0.0795104 & 0.1457341 & 0.04059887 \\
$\mathbf{2 0 1 1}$ & 0.09396559 & 0.1296828 & 0.04896527 \\
$\mathbf{2 0 1 2}$ & 0.1177569 & 0.149074 & 0.06672682 \\
$\mathbf{2 0 1 3}$ & 0.1300533 & 0.3863547 & 0.07166745 \\
$\mathbf{2 0 1 4}$ & 0.1411518 & 0.3171471 & 0.08459407 \\
$\mathbf{2 0 1 5}$ & 0.1475089 & 0.4659078 & 0.09828729 \\
$\mathbf{2 0 1 6}$ & 0.1569462 & 0.4499682 & 0.1201707 \\
\hline
\end{tabular}

The following figure shows the variation curves of the potential function of economic value, ecological value and social value subsystems of forest (Fig. 1). It can be seen that since 2009, the forestry economic value in China has increased year by year and the social value has also increased, showing that Chinese forestry keeps developing and the social economy is also growing. The reason is that on one hand, the output value of the forestry industry is increasing year by year, and contributions of the secondary industry and tertiary industry are increasing; on the other hand, the level of urbanization is increasing and the per capita income of forestry people rises as well. The curve of ecological value 
of forest is more fluctuating, showing an inverted U-shape development. The rising of ecological value curve in 2009 indicates increasing carrying capacity of forest environment, and this is inseparable from the afforestation area and forestry ecological construction in that year.

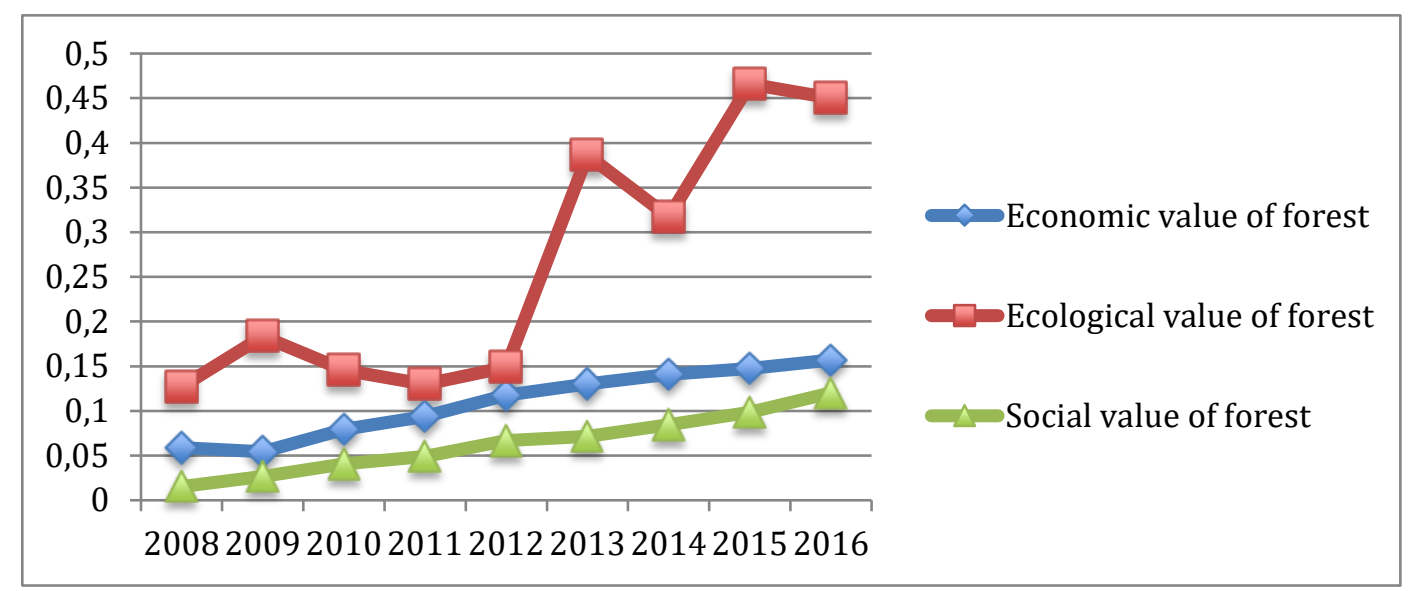

Figure 1. Variation curves of the potential function of subsystems of forest value

There was an inflection point in 2011 with the minimum of 0.129 . The reason may be related to the forestry development policy in recent years such as the reform of collective forest property right system. In addition, forest is a complex system integrating the primary industry (forest management, etc.), the secondary industry (wood processing, etc.), and tertiary industry (ecological service construction, etc.), increase in the primary industry can promote the development of tertiary industry, and efforts in ecological construction can also increase the output value of the primary industry. For the output value of forestry industry in the past few years, the output value of the second industry was the largest in 2011, while such increase would inevitably lead to excessive exploitation and utilization of forest resources, resulting in imbalanced forest resource structure. This, together with an increase in the damage area of forest and decrease in the construction of ecological protection, will inevitably lead to degradation of forest ecosystem and the lowest ecological value of forest.

In addition, when studying the weight of each subsystem, the author finds that the weight of each indicator in subsystems of forest value is higher than other indicators, and their rankings are higher; therefore, the author adjusts the parameters in the coordination function with the adjusted ratio of $\alpha: \beta: \gamma=4: 21: 1$, and takes them into the coupling coordination model to obtain Table 6.

It can be seen from the data in Table 6 that the coupling coordination degree among subsystems of forest value showed a fluctuating rise from 2008 to 2016, and it increased by one level from 2013 with the highest increase. The reason is that in 2011, the State Council held Working Conference on National Natural Forest Resources Protection 
Project, and State Forestry Administration actively implemented the spirit of the conference and held Work Arrangement Conference on the $2{ }^{\text {nd }}$ Phase of National Natural Forest Resources Protection Project, requiring to further implement the forest management subsidy and related social insurance subsidy policies; meanwhile, State Forestry Administration also issued Twelfth Five-Year Plan for Forestry Development, which affirmed the achievements of forestry construction during the Eleventh Five-Year Plan period, pointed out the three major goals of forestry construction (i.e., to build a sound forestry ecosystem, a developed forestry industry system, and a prosperous ecological and cultural system) to achieve scientific development and sustainable development of forestry, took construction of ecological civilization as the primary task of developing forestry, and clearly gave forestry five main functions including ecological function, economic function, social function, carbon sink function and cultural function, and set the main indicators for forestry development during the Twelfth Five-Year Plan period.

Table 6. 2008 to 2016 calculation result of coupling coordination degree $T$ after adjusting coefficient

\begin{tabular}{c|c|c|c|c|c|c|c|c}
\hline $\mathbf{2 0 0 8}$ & $\mathbf{2 0 0 9}$ & $\mathbf{2 0 1 0}$ & $\mathbf{2 0 1 1}$ & $\mathbf{2 0 1 2}$ & $\mathbf{2 0 1 3}$ & $\mathbf{2 0 1 4}$ & $\mathbf{2 0 1 5}$ & $\mathbf{2 0 1 6}$ \\
\hline 0.081 & 0.114 & 0.115 & 0.112 & 0.133 & 0.261 & 0.242 & 0.321 & 0.330 \\
\hline
\end{tabular}

Therefore, under such policy, the coupling coordination indicator of forest values rose greatly from 2012 and increase in the ecological value of forest played a crucial role (Zhang et al., 2017). The reason for fall in 2014 was that the afforestation area in 2014 was 550.45 million hectares less than that in 2013, at the same time, the construction area of natural forest protection project and the area of sand control project were also less than in 2013, and slow growth of forest ecological construction caused slow increase in the ecological value of forest and reduced coupling coordination degree among forest values (Martínez, 2019). To sum up, it can be seen from the above that the development of ecological value of forest plays an important role in the development of the entire forestry economy, and insisting on implementation of afforestation, development of six major forestry projects, and development of forest recreation value is an inevitable choice for China to develop forestry economy as well as a necessary condition for sustainable development of forestry (Asgari, 2018).

To reflect the role of the ecological value of forest in the total value of forest more clearly, the coupling coordination degree $\mathrm{T}^{\prime}$ after adjusting coefficients is compared with the coupling coordination degree $\mathrm{T}$ before adjustment (Fig. 2). 


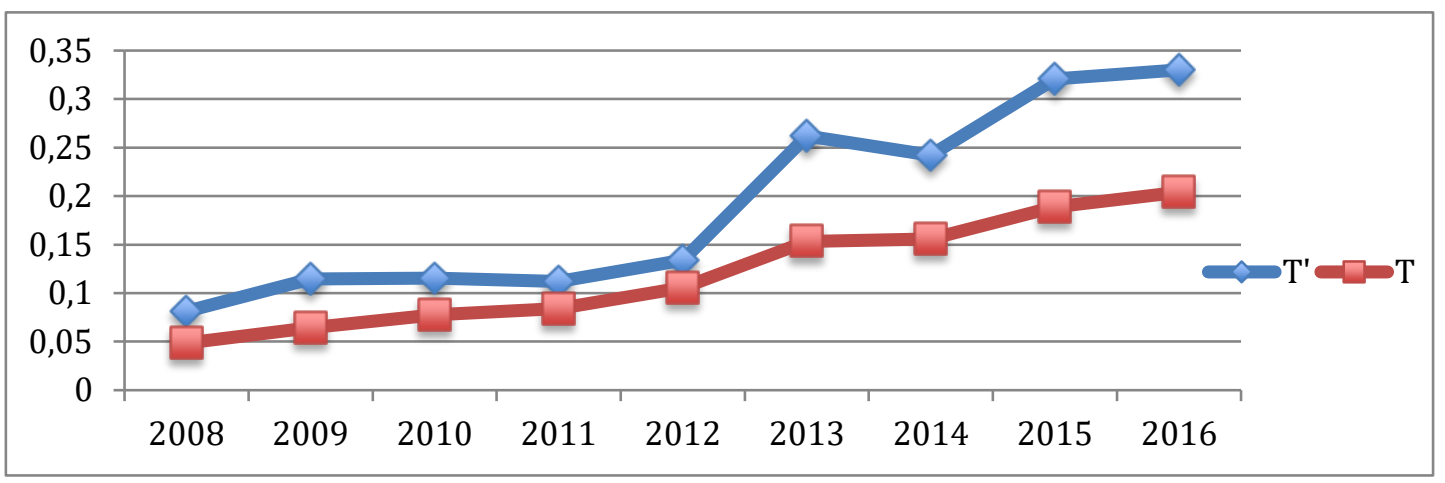

Figure 2. Comparison analysis of coupling coordination degree after adjusting coefficient

It can be seen clearly that from 2012, the ecological value of forest greatly increased the coupling coordination degree among the total values of forest, having better function in coordination and development of subsystems.

\section{Conclusion}

This study uses potential function and the coupling effect in physics to build a coupling model, conducts research on the economic value, ecological value and social value of forest from the quantitative point of view, and builds indicator systems from nine perspectives respectively including economic benefit, economic structure, ecological basis, ecological structure, forest health condition, ecological protection function, value of people's livelihood, tourism value of forest, and cultural value of forest (Zeng et al., 2018); it also studies the coupling relationship among economic value, ecological value and social value of forest in China from 2008 to 2016 and draws the following conclusions:

(1) The overall coordination degree among economic value, ecological value and social value of forest in China is poor. The coordination degree of all samples was at the level of poor coordination before 2016 and entered into the level of weak coordination after 2016 (Lu et al., 2019). Both levels belong to the state of slow and uncoordinated development, but the ecological value of forest always accounted for a higher proportion than economic value and social value. Therefore, China should continue to adhere to the construction of ecological civilization, improve the ecological environment of forest, and enhance the level of coordination degree of forest values.

(2) From the perspective of national policies, in 2011, State Forestry Administration promulgated the Twelfth Five-Year Plan for forestry and began to implement the $2^{\text {nd }}$ Phase of National Natural Forest Resources Protection Project, having an important impact on the promotion of the ecological value of forest. After 2012, the coordination degree among forest values also improved faster than before and gradually developed to the upper level. This also shows that the promotion of the ecological value of forest can 
more effectively promote the economic value and social value of forest so that the relationship among forest values would become more harmonious, and developing the ecological value of forest is an important measure to achieve sustainable development of forest in future.

(3) From the perspective of the index weight of subsystems, what impacts greatly on the weights of index systems is mainly concentrated in the ecological value subsystem of forest with afforestation area accounting for the largest proportion. Therefore, China should adhere to afforestation and restore forest ecological barrier. Secondly, the value of forest tourism has increased year by year with its weight also higher compared with the index in other social value subsystems. This shows that with the development of society, people have better payment ability and increasing recognition that forest tourism can bring more physical and mental pleasure. People's willingness to return to nature and close to nature rises, and the income of national forest tourism also rises continuously. Development of forest tourism can promote the overall increase of the social value and economic value of forest. From the economic structure of forestry industry, with the increasing output value of the tertiary industry of forestry, the potential function value of economic value of forest also increases year by year, showing that the tertiary industry of forest and the economic value of forest are positively related, and active development of the tertiary industry of forest will help improve the economic and ecological value of forest.

(4) By adjusting the parameters of the coupling coordination model, we can clearly see the impact of the ecological value of forest on the overall forest value coordination model. However, increase in only the ecological basis and ecological protection function of forest is not enough to improve the ecological value of forest and exert the ecological benefits of forest, and the country must give certain financial support. Although the country started pilots for ecological benefit subsidy in 2001 and provided certain ecological construction investment every year, ecological subsidy still accounted for a small proportion, not enough to compensate the speed of ecological damage. Therefore, China should promulgate relevant laws and regulations, follow the principle of "whoever benefits shall pay" and "whoever damages shall compensate", and charge certain ecological compensation fee from the direct beneficiaries and direct wrongdoers of forest ecology to increase forest ecological compensation funds, improve social awareness of ecological construction and environmental protection, and promote sustainable development of forests (Zhang et al., 2017).

Forest ecological protection work is a systematic project that needs the participation of the whole people. It needs the strength of the people to complete. Therefore, if we want to achieve the protection of forest ecological resources, we must do a good job in propaganda, enhance the awareness of the importance of forest protection, let them fully realize the importance of forest ecological resources protection, consciously participate in the ranks of forest ecological resources protection. 
Acknowledgements. This work was supported by Humanity and Social Science foundation of Ministry of Education of China 16YJA630072.

\section{REFERENCES}

[1] Ali, W., Nasir, M. S., Nasir, A., Rashid, H., Ayub, I., Gillani, S. H., Latif, M. J. (2018): Assessment Of Carbon Footprints In Terms Of Co2 Of Diesel Generator, Pakistan. - Earth Sciences Pakistan 2(1): 15-17.

[2] Asgari, A. (2018): 1. Methods for breaking Chinese lantern (Physalis alkekengi L.) seed dormancy. Laboratory and greenhouse studies. - Revista de la Facultad de Agronomia de la Universidad del Zulia 35(2).

[3] Austin, O. E., Ebuka, A. O., Zanders, A. C. C., Joseph, I. N. (2018): Seismic Analysis Of The Transgressive Systems Tracts (TSTS) Of The Niger Delta. - Earth Sciences Malaysia 2(2): 16-19.

[4] Babaranti, O., Horn, S., Jowett, T., Frew, R. (2019): Isotopic signatures in Mytilus galloprovincialis and Ulva latuca as bioindicators for assessing discharged sewage effluent in coastal waters along Otago Peninsula, New Zealand. - Geology, Ecology, and Landscapes 3(1): 53-64.

[5] Chen, C., Song, H., Yang, H. (2017): Liouville type theorems for stable solutions of pLaplace equation in RN. - Nonlinear Analysis 160: 44-52.

[6] Cong, R. Z., Wang, B., Gu, J. C., Niu, X., Hu, T. H. (2017): Evaluation of forest ecosystem services values of Helan Mountain National Nature Reserve, Ningxia. - Journal of Arid Land Resources and Environment 31(11): 136-140.

[7] Dali, N. M., Kamarudin, K. S. N. (2018): The Effect of Cosurfactant In Co2 Absorption In Water - In - Oil Emulsion. - Environment \& Ecosystem Science 2(2): 42-46.

[8] Deng, K. M., Shi, P. L., Xie, G. D. (2002): Water conservation of forest ecosystem in the upper reaches of Yangtze River and its benefits. - Resources Science 24(06): 68-73.

[9] Dong, P. W., Zhang, X. (2013): Measurement study on system coupling between forestry and forest ecosystems. - China Soft Science (11): 178-184.

[10] Dong, W., Tian, S. Y., Li, Y. (2017): Dynamic trend of forestry eco-economic development: theoretical model and regional differences. - East China Economic Management 31(11): 44-50.

[11] García-Nieto, A. P., García-Llorente, M., Iniesta-Arandia, I., Martín-López, B. (2013): Mapping forest ecosystem services: From providing units to beneficiaries. - Ecosystem Services: 126-138.

[12] Gautam, A., Batra, R., Singh, N. (2019): A Study On Use Of Rice Husk Ash In Concrete. - Engineering Heritage Journal 1(1): 01-04.

[13] Hernández, C. (2019): Evaluating the Efficiency of Rice Plant Growth. - Revista de la Facultad de Agronomia de la Universidad del Zulia 36(1).

[14] Jamil, F., Arshad, R., Ali, M. A. (2018): Design, Fabrication And Evaluation Of Rotary Hot-Air Dryer For The Value Addition Of Fruit Waste. - Earth Sciences Pakistan 2(2): 0711.

[15] Li, X. Y., Zhao, Q. L. (2017): A new integrable symplectic map by the binary nonlinearization to the super AKNS system. - Journal of Geometry and Physics 121: 123137.

[16] Liao, B., Zhang, Z. G. (2017): The empirical measurement of coupling from indicators to indexes of forestry ecological security. - Resources Science 39(9): 1777-1791.

[17] Liu, D. Q., Huang, Q. (2007): Theoretical investigation and innovation of coordinating forestry ecological benefits and economic benefits. - Public Finance Research (11): 25-27. 
[18] Lu, D., Feng, L., Jie, P. (2019): Solar Cells Various Appearance Defects Automatic Simultaneous Detection System of the Greenhouses. - Acta Microscopica 28(1).

[19] Majumder, S. C., Islam, K., Hossain, M. M. (2019): State of research on carbon sequestration in Bangladesh: a comprehensive review. - Geology, Ecology, and Landscapes 3(1): 29-36.

[20] Martínez, R. (2019): Experiments to Improve Sugarcane Production in Cuba. - Revista de la Facultad de Agronomia de la Universidad del Zulia 36(1).

[21] Meza, N. M. (2018): 2. Evaluación de características de calidad de clones promisorios y variedades de papa (Solanum tuberosum L.). - Revista de la Facultad de Agronomia de la Universidad del Zulia 35(2).

[22] Olivares, B., Cortez, A., Lobo, D., Parra, R., Rey, J., Rodríguez, M. (2017): Evaluación de la vulnerabilidad agrícola a la sequía meteorológica en diferentes localidades de Venezuela. - Revista de la Facultad de Agronomía 34(1): 103-129.

[23] Pang, Z. H., Liu, G. P., Zhou, D., Sun, D. (2016): Data-based predictive control for networked nonlinear systems with network-induced delay and packet dropout. - IEEE Transactions on Industrial Electronics 63(2): 1249-1257.

[24] Pascual-Córdova, G. (2018): Indicadores de calidad del suelo en el agroecosistema caña de azúcar (Saccharum spp.). - Revista de la Facultad de Agronomia de la Universidad del Zulia 35(1): 88-95.

[25] Sarwar, M. T., Hui, Z. H., Maqbool, A. (2019): Causes And Control Measures Of Urban Air Pollution In China. - Environment \& Ecosystem Science 3(1): 35-36.

[26] Shan, P. F., Lai, X. P. (2018): Numerical Simulation of the Fluid-Solid Coupling Process During the Failure of a Fractured Coal-Rock Mass Based on the Regional Geostress. Transport in Porous Media 124(3): 1061-1079.

[27] Shrestha, A., Baral, S. (2018): Socioeconomic Factors Affecting Awareness And Adaption Of Climate Change: A Case Study Of Banke District Nepal. - Earth Sciences Malaysia 2(2): 20-24.

[28] Tao, S. (2018): Evaluation Of Technology Innovation In Hubei Province. - Engineering Heritage Journal 2(2): 09-10.

[29] Wang, E. D., Li, L., Wei, J. H. (2015): Economic value evaluation of resources and management attributes for forest parks using choice experiments. - Resources Science 37(01): 193-200.

[30] Wang, W. J., Hu, X. X., Zhao, M. (2015): Forest recreation value estimation based on producer perspective. - Statistics and Decision 3: 14-17.

[31] Wang, Y. (2019): Influencing Factors of Water-saving Irrigation Technology Used by Vegetable Growers from the Perspective of Cost-benefit. - Revista de la Facultad de Agronomia de la Universidad del Zulia 36(1).

[32] Wu, S., Yan, X. D., Zhang, L. J. (2014): The relationship between forest ecosystem energy and forest ecosystem service value in China. - Acta Geographica Sinica 69(03): 334-342.

[33] Yang, Y. X., Li, H., Zheng, W. K., Yun, B., Liu, Z. M., Zhang, J. J. (2019): Experimental Study on Calcining Process of Secondary Coated Ceramsite Solidified Chromium Contaminated Soil. - Science of Advanced Materials 11(2): 208-214.

[34] Zeng, D., Qiu, Y., Peng, S., Chen, C., Zeng, J., Zhang, S., Xiao, R. (2018): Enhanced hydrogen production performance through controllable redox exsolution within $\mathrm{CoFe} A 1 O$ x spinel oxygen carrier materials. - Journal of Materials Chemistry A 6(24): 11306-11316.

[35] Zhang, C., Ren, Z. Y., Gao, M. X., Yan, W. H. (2007): The forest ecosystem services and their valuation in Gansu Province. - Journal of Arid Land Resources and Environment 21(08): 147-151.

[36] Zhang, C. H. (2016): Developing situations of forestry in Xinjiang Province based on the time series \& PCA. - Journal of Arid Land Resources and Environment 30(02): 58-62. 
[37] Zhang, W., Ma, L., Zhang, T. (2017): Discrete-time mean-field stochastic H 2/Hœ control. - Journal of Systems Science and Complexity 30(4): 765-781.

[38] Zhang, W., Yang, J., Fang, Y., Chen, H., Mao, Y., Kumar, M. (2017): Analytical fuzzy approach to biological data analysis. - Saudi journal of biological sciences 24(3): 563-573.

[39] Zhang, Y., Li, Y., Bai, C. (2017): Microstructure and oxidation behavior of Si-MoSi2 functionally graded coating on Mo substrate. - Ceramics International 43(8): 6250-6256.

[40] Zhang, L., Khalique, C. (2018): Classification and bifurcation of a class of second-order odes and its its application to nonlinear PDES. - Discrete \& Continuous Dynamical Systems-Series S 11(4).

[41] Zhou, D. M., Al-Durra, A., Matraji, I., Ravey, A., Gao, F. (2018): Online Energy Management Strategy of Fuel Cell Hybrid Electric Vehicles: A Fractional-Order Extremum Seeking Method. - Transactions on Industrial Electronics 65(8): 6787-6799. 